\title{
SOUTH AFRICA'S OPERATION PHAKISA: DEVELOPMENT WITHOUT SECURITY?
}

\author{
Lisa $\mathrm{Otto}^{1}$
}

\begin{abstract}
In the years since the end of the Cold War, a growing body of literature has emerged discussing the nexus between development and security, holding that these are linked closely and mutually reinforcing. Thinking around the security-development nexus has been extended into the maritime domain, with an increasing recognition of the connection and interdependence of the land and sea, and that secure seas are seen as a vital condition for positive development trajectories emanating from the Blue Economy. This sentiment is increasingly reflected in domestic and regional maritime security strategies and policies, including in the African Union's African Integrated Maritime Strategy 2050 (AIMS 2050). Despite its leadership in developing a maritime security strategy for the Southern African Development Community (SADC), it can be argued that security is dangerously underplayed in South Africa's key maritime project, Operation Phakisa. This article presents an analysis of the development-security nexus at sea, an assessment of South Africa's approach to its maritime security, and the results of a careful examination of Operation Phakisa. The article concludes that there is an urgent need for a review of South Africa's maritime arena, to truly understand challenges emanating from the sea and how these will affect the development South Africa wishes to derive from it.
\end{abstract}

Key words: maritime security, South Africa, Blue Economy, Operation Phakisa, security-development nexus

\section{Introduction}

In recent years, maritime security has seen growing importance on the global agenda. Nowhere has this been more true than in Africa, which, following a previous position of 'sea-blindness', is now increasingly seeing territorial waters as an extension of state sovereignty, bringing with it both challenges and opportunities. By embracing the Blue Economy (in other words the economic opportunities offered by the sea, viewed from a sustainable development perspective) and recognising how this can play a central role in terms of positive development trajectories, securing the seas by addressing the challenges presently posed in the maritime domain has become of vital importance. This has been reflected in the wave of maritime security strategies developed across the region, and indeed also continentally at the African Union (AU) in the form of the African Integrated Maritime Strategy 2050 (AIMS 2050).

South Africa has had a slow start in getting involved in maritime security issues, doing so only several years after Somali piracy arose as a major problem, and when it seemed that pirates may close in on the Mozambican Channel. Subsequent to this, al- 
though perhaps more closely linked to the oceans debate than South Africa's anti-piracy efforts, the country developed Operation Phakisa, an arm of the National Development Plan (NDP), that would help South Africa maximise its economic opportunities at sea, by spurring economic growth and creating jobs. ${ }^{2}$ For lack of another policy or strategy that is maritime-focused, this could be considered South Africa's framework for approaching the seas. The only other initiative that could potentially fit this bill is "Research Innovation and Knowledge Management Road Map for the South African maritime sector", which was published by the Council for Scientific and Industrial Research (CSIR) in $2017^{3}$. This Road Map spends half a page mulling over security concerns, and notes the need for a maritime safety and security information centre, while also emphasising that South Africa should develop a maritime security strategy. Nonetheless, although the CSIR falls under the authority of the Minister of Science and Technology, the document describes itself as a sector initiative that brings together public and private stakeholders. It can thus not be considered a policy document in and of itself. While it therefore brings useful suggestions, these are themselves policy recommendations. The growing appreciation that development and security go hand in hand, particularly with respect to the Blue Economy, remains absent from South Africa's conceptualisation of its blue opportunities.

The study on which this article reports, aimed to assess Operation Phakisa as the key tenet of South Africa's seaward gaze, and to consider the question of how South Africa can achieve ocean-based economic development objectives without taking a more strategic view on security within the country's territorial waters and exclusive economic zone (EEZ). The article begins by illustrating the nexus between security and development at sea, showing how others have closely connected their economic ambitions with the ability to ensure that the maritime domain is secured in the sense that maritime threats and challenges are being addressed actively. It then looks at South Africa and its maritime security, homing in on Operation Phakisa and the challenges in the country's sea-space. The study reported here thus concluded that development without security is unlikely to be possible for South Africa, and that government will need to refocus its approach in order to be able to achieve the Blue Economy goals that are being pursued.

\section{The security-development nexus at sea}

Since the end of the Cold War, there has been a growing understanding that development cannot happen without security. In explaining this, Johansson quotes erstwhile United Nations Secretary General Kofi Annan's comment, "humanity will not enjoy development without security and will not enjoy security without development". ${ }^{4}$ Hrychuk elucidates that the underlying premise of the security-development nexus is "security and development are intrinsically linked and mutually reinforcing ... in the same way that security requires a minimum level of development, development cannot occur unless security is ensured". Hettne highlights that it is becoming increasingly clear that there is empirical evidence to these links between security and development. ${ }^{6}$

Security can be understood narrowly as the "protection of the territorial integrity, stability, and vital interests of states through the use of political, legal, or coercive in- 
struments", ${ }^{7}$ in this case, at state level. When more broadly conceived, security comprises the protection of the economy and the environment, and the provision of human security, which itself spans broad threat areas (such as food security, community security, political security and so on). This places humans rather than national interest at the centre. Development, meanwhile, is the "processes and strategies through which societies and states seek to achieve more prosperous and equitable standards of living". ${ }^{8}$ Again, development can also be more broadly interpreted, and can be seen to include trade, wealth creation, community safety and security, and the provision of other such public goods. Of course, this article refers more specifically to economic development; thus, the creation and exploitation of opportunities to increase a population's standard of living and receipt of public goods by maximising existing industries and harnessing new ones.

While the literature on the security-development nexus centres much on development in the context of war, it can also be understood that insecurity comes not only in the form of violent conflict but can also be caused by criminal activity or violent actions, which have financial/criminal motives and exist outside of the context of war or conflagration. Indeed, Green and Otto explain, "conflict can be described as occurring on a broad spectrum, from full-scale civil war and rebellion, at the one end, to local riots and peaceful, non-violent protests, at the other", which may have ethnic, political, cultural, or economic dimensions.

Thinking around the security-development nexus has been extended into the maritime domain. Swanepoel, for one, argues that there is an increasing recognition of the connection between and an interdependence of the land and sea. In addition, there is the notion that "the sustainable use of the abundant goods and services supplied by the ocean, as well as the adaptation to and mitigation of the risks or dangers that the ocean presents to prosperity" are linked..$^{10}$ Indeed, there are numerous challenges, which affect the security of the maritime domain, including but not limited to piracy and armed robbery, illegal, unreported and unregulated (IUU) fishing, fisheries crime, human trafficking, irregular migration, and the smuggling of a host of illegal goods. ${ }^{11}$ Swanepoel notes that, among other things, security at sea for the sake of development implies that maritime transportation systems must be safe from transnational organised crime at sea, and that the lawlessness in general, which persists at sea, must be tackled..$^{12}$ Indeed, this linkage between security and development in the maritime context becomes self-evident when one considers the interplay, for example, between the fisheries industry, economic imperatives under Blue Growth agendas, and human and community security. The protection of fish stocks, and thus the ability for small-scale and commercial fishers to continue their businesses sustainably, depend on the capacity of states to provide oversight and enforcement in this area.

Further to this, it can be inferred that another area where the security-development nexus comes into play is in implementing Sustainable Development Goal 14 - to conserve and sustainably use the oceans, seas and marine resources ${ }^{13}$. When considering the targets encapsulated by this goal, we can see that security in various forms is necessary: in preventing pollution, in combatting overfishing and IUU fishing, for the conservation 
of certain coastal and marine areas, and in increasing the economic benefits accrued to developing states through the sustainable use of marine resources. ${ }^{14}$ In her work, Van Wyk highlights countries that had, at the time of her writing, focused on the concept of the Blue Economy, which she notes has become a subject of interest for many multilateral organisations, with several states, notably Small Island Developing States (SIDS), including a Blue Economy perspective in their development plans and policies. ${ }^{15}$

Further to this, many maritime strategies conceive of themselves as security strategies, with this outlook being conveyed in their names. For example, the European Union (EU) strategy is entitled "The EU Maritime Security Strategy and Action Plan", while the United Kingdom (UK) has its "National Strategy for Maritime Security". The United States of America (USA), Brazil, India, China, and Japan are other countries that also have maritime security strategies.

The EU provides the following explanation in the very opening lines of its strategy: "the EU depends on open, protected and secure seas and oceans for economic development, free trade, transport, energy security, tourism and good status of the marine environment"16. The UK conceptualises of its need for having such a strategy in place as emerging from a requirement to secure its economic prosperity "by outlining cross-government priorities, this strategy sets out the whole-of-government approach, including our reliance on international partners, required to secure the seas and oceans that Britain depends upon for its national security and economic well being". ${ }^{17}$ The US National Strategy for Maritime Security also highlights at the outset, "the safety and economic security of the United States depends upon the secure use of the world's oceans". ${ }^{18}$ This strategy aims in particular to prevent criminal or hostile acts, protect critical infrastructure, minimise damage and expedite recovery from attacks at sea, and to safeguard the ocean and its resources from unlawful exploitation and intentional critical damage. Similarly, in Brazil, "the prospect of tapping into ... maritime resources on a commercial scale" prompted the government to include the South Atlantic Ocean in its 2008 National Defence Strategy and its 2012 Defence White Paper. ${ }^{19}$ India's strategy is premised on the notion that it has a "strategic need to preserve peace, promote stability and maintain security within a regional and global framework, so as to alleviate poverty and promote all-round socio-economic development". ${ }^{20}$ Meanwhile, while its strategy focuses on security in the Asia-Pacific region more generally, China still explicitly recognises that security in this region is necessary for "laying a solid economic foundation". ${ }^{21}$ The Japanese make use of their strategy to ensure environmental conservation and sustainable development in the country's EEZ, which extends to the exploitation of resources on islands where Japan wishes to claim sovereignty. ${ }^{22}$

Coming back to Africa, we see in AIMS $2050^{23}$ a clear linkage between its development agenda and insecurity at sea. The strategy notes that threats to security in the maritime domain hold a "potential impact on the prosperity derivative" given that the African maritime domain holds great potential for wealth creation for African states, which would in turn benefit development. It thus places emphasis on the need to protect, regulate and manage Africa's maritime resources. 


\section{South Africa and maritime security}

It is worth making some mention of South Africa's maritime geography before examining its maritime security. South Africa finds itself at the tip of a continent, with its coastline straddling two oceans, which are home to historically important sea lines of communication (SLOCs). On its west coast lies the Atlantic Ocean with the Indian Ocean on its eastern coastline, and to its south there is also the Southern Ocean. South Africa further has two islands, which lie nearly $2000 \mathrm{~km}$ southeast of the main landmass - Prince Edward Island and Marion Island. Cumulatively, when one takes into consideration the country's EEZ, South Africa has a sizeable territory, and a continental shelf claim could see the country expand its territory, which would effectively render South Africa's landmass smaller than its ocean territory. ${ }^{24}$ This has led van $\mathrm{Wyk}^{25}$ to refere to South Africa's maritime domain as its ' $10^{\text {th }}$ province'.

Whilst South Africa has been involved in maritime security initiatives, its participation has been tardy. Although Somali piracy had begun to rise as a concern of global proportions in 2007, it was only in 2010 that South Africa became more formally involved in operations countering piracy, then the key focus of global maritime security concerns.

South Africa's approach here has been an exercise in pragmatic foreign policy. ${ }^{26}$ It launched Operation Copper to assist Mozambican forces following an attack by Somali pirates off the Mozambican coastline at the request of that country's government, and it was not until two years later that South Africa formalised its anti-piracy contribution (ironically in the same year that Somali piracy had begun to decline). Until this time, South Africa's only other involvement has been the role it played in the process of developing the SADC Maritime Security Strategy, which was signed in 2011, ${ }^{27}$ and which an observer notes was largely written by South Africa. ${ }^{28}$ In 2012, South Africa joined a trilateral initiative under the auspices of the SADC to commence a collective project of securing the Mozambican Channel, in theory, to keep it safe from the outward ballooning of the range of operations of Somali pirates. ${ }^{29}$

These have been South Africa's only engagements with maritime security at a regional and international level apart from expressions of moral support over issues of maritime security and participating in joint training exercises from time to time on the continent and with international partners.

A pragmatic observer may suggest that this is an adequate level of involvement given that the country does not face the same immediate threats to maritime security as are seen elsewhere on the continent, such as in West Africa, for example. Others may note that South Africa has the most powerful military in sub-Saharan Africa along with the best-equipped navy. Moreover, being an anchor state on the continent, the country should take a leading role in solving pressing African challenges, of which maritime insecurity is clearly one. This latter view is bolstered by South Africa's frequent use of its defence force as a foreign policy actor, particularly on the African continent where it deploys forces to join United Nations and African Union missions. ${ }^{30}$ However, questions 
remain as to why South Africa, via its Navy, still seems to have a disproportionate focus on the issue of piracy. Piracy has dwindled significantly off Africa's east coast, posing little to no threat to South Africa or the SADC. In addition, West African piracy does not stretch much further down the west coast than Angola, where it all but peters out.

However, the issue of the maritime domain has now gained greater importance as a domestic imperative, with South Africa launching Operation Phakisa in 2014, a socalled legacy project for former president Jacob Zuma. Operation Phakisa is an initiative that aims to balance the interdependencies and overlapping responsibilities of various departments and to provide concise and coherent direction toward a cross-sectoral approach to ocean governance and the enhancement of the Blue Economy. ${ }^{31}$ Phakisa focuses on marine transport and manufacturing, offshore oil and gas exploitation, aquaculture and marine protection services, and ocean governance. ${ }^{32}$ Notably, Operation Phakisa is intended to integrate the response from government and harness the opportunities presented by the Blue Economy to address two of South Africa's most pressing challenges: widespread unemployment and a flailing economy.

Of course, whilst South Africa's continental engagement has had the Navy at its centre, domestic approaches to maritime security naturally involve a broader set of actors. The South African Police Service (SAPS) has responsibility for policing within territorial waters, while the Department of Agriculture, Forestry and Fisheries (DAFF) has functions relevant to the management of fisheries, and the Department of Environmental Affairs (DEA) likewise must see to environmental protection. These actors must thus work in concert to address challenges and threats within the South African maritime domain.

Although devised in the context of strategies to provide for developmental needs, particularly the country's well-meaning but yet unimplemented NDP, there is a distinct lack of a maritime security element to what is South Africa's key sea-facing initiative. A survey of publicly available documents promoting Operation Phakisa on their website, as well as President Jacob Zuma's October 2014 speech at the Operation Phakisa Open Day in Durban shows not a single mention of the word 'security'. Instead, the focus of these materials is on economics, fast growth and the creation of jobs in the context of a country with high levels of unemployment. Indeed, a naval official suggests that the Navy would likely have been more interested in having a clearer role in Operation Phakisa if security was overtly included. The Navy did not necessarily support the concept of Operation Phakisa but realised at a strategic level it would be more likely to have funds allocated for its own needs should it find a way to link their own projects and works to Operation Phakisa. ${ }^{33}$

Perhaps this overly economic approach can be explained by the prevailing notion that South Africa faces no threats to maritime security - no pirates lurk nearby, it has no extensive offshore oil industry that could face harassment as seen in Nigeria, and the country exists in a relatively peaceful neighbourhood where it nonetheless has the strongest naval power of all. 
Yet, while there are no tense territorial disputes, as for example between Somalia and Kenya following oil and gas discoveries, or the long-standing quarrel over the Cabinda region in Angola, measures for dealing with territorial disputes with Namibia and Mozambique have been put in place. ${ }^{34}$ Further, although human trafficking and forced labour do not spring to mind in relation to South Africa in the way that it might in Southeast Asia for example, South Africa does experience irregular migration by sea, with Senu highlighting the case of stowaways who board vessels in South African harbours to seek new lives elsewhere. Some of the more pressing challenges, however, come in the form of IUU fishing and in the trafficking of illicit goods. ${ }^{35}$

Indeed, recent reports flagged up that there might be more in the way of threats to maritime security than initially meets the eye. In May 2016, three Chinese skippers were charged with fishing without the requisite permits in South African waters, having looted R70 million worth of squid. ${ }^{36}$ Indeed, research has shown estimates that IUU fishing may cost the South African economy as much as R60 billion per year. ${ }^{37}$ While awareness around the prevalence of illegal fishing and fisheries crime in other parts of Africa has been increasing (highlighted, for example, with the publication in 2016 of research by the Overseas Development Institute entitled 'Western Africa's missing fish' $)^{38}$, illegal fishing in South African waters has often largely been deemed to constitute the harvesting of abalone, a protected species of shellfish. The 2016 incident (see above) harks back to the Bengis case, where the illegal harvesting of rock lobster over a 14-year period was brought to an American court in 2013 and resulted in a US\$22.5 million reparations payment to South Africa. ${ }^{39}$ Amounting to roughly R320 million at the time of writing, this amount is but a drop in the ocean, so to speak, when compared to the earlier figure cited by Kings ${ }^{40}$. It also represents a considerable loss of income for South Africa and of employment opportunities in the country.

The issue of fisheries crime is a potent example in highlighting the need for further research to understand the challenges posed to South Africa's maritime security fully. It also makes clear that more is needed to protect the Blue Economy, which Operation Phakisa seeks to nurture.

Smuggling is another crime by which South African water borders are currently being exploited. While many forms of smuggling and trafficking occur across the terrestrial borders, illicit goods often leave the continent via seaports in other African countries. As far as South Africa is concerned, seaports are often used by drug smugglers. Research conducted by Van Heerden found that Durban Harbour has been a particularly important transit point for the smuggling of cocaine that has arrived from Latin American countries, such as Brazil, Chile, Colombia and Venezuela. ${ }^{41}$

These breaches of security in South Africa's maritime domain, beg some questions with respect to the country's maritime domain awareness (MDA):

- How clear is the picture relevant South African authorities have on what is happening in South African waters? 
- Are these authorities aware - at any given time - of the vessels that may be in South African territorial waters not for the purpose of safe passage but to conduct illegal activities?

- Do the authorities implement the portside measures contained in the International Ship and Port Facility Security (ISPS) Code fully in order to detect and prevent security threats?

In order to answer these questions, the author conducted a number of interviews to gain insights into criminal activities in South African waters, and the country's prevention, policing and defence capabilities, largely because little information on this is available in the public domain. An engineer at the Council for Scientific and Industrial Research (CSIR), which performs a monitoring role of South Africa's maritime domain, responded to the suggestion that South Africa's MDA is patchy by saying that the country's capabilities are improving but that enforcement remains a challenge, as there is but one enforcement vessel responsible for the entirety of the country's territorial waters. $^{42}$ The key initiative being employed to develop these capabilities is SeaFAR, which uses "satellite-based aperture radars to monitor the deep ocean to detect and identify vessels that exhibit suspicious behaviour", but this too requires improvement as data is produced through periodic sampling. ${ }^{43}$ However, encouraging reports emerged from the Department of Science and Technology (DST) in February 2019 where it affirmed its commitment to the planned nanosatellite programme for MDA, committing further resources over the next three years. ${ }^{44}$ Another observer agrees that South Africa's MDA is changing for the better but that the process is slow, being of the view that the National Oceans and Coastal Information Management System (OCIMS) is "doing well" ${ }^{45}$ This observer however noted that MDA is only ever as good as a patrol capability of a state. He continued by referring to the great importance of being able to launch action on the basis of intelligence, while lamenting that the SADC's MDA sensors are not operational. In the same vein, Project Biro, which sees to the provision of three inshore patrol vessels, is a positive development that will improve inshore patrol capabilities, whilst also boosting the country's shipbuilding industry.

As far as the ISPS Code is concerned, Transnet, the state-owned enterprise responsible for ports and railways, notes that South Africa's seven commercial ports became IPSP compliant in June 2004, with efforts having been employed to upgrade security measures, plans and processes. ${ }^{46}$ South Africa also put in place legislation by way of the Merchant Shipping (Maritime Security) Regulation, 2004 ${ }^{47}$. Ramsaroop notes that South African ports maintain ISPS Code status and are thus regarded safe, and that implementation of the requisite measures has resulted in a decreased crime rate at ports. ${ }^{48}$ What is unclear, however, from Ramsaroop's research is whether corruption and malfeasance are present at ports, as ISPS implementation seems to be accepted at face value. Chêne, writing for the Anti-Corruption Resource Centre, notes that there is little research on corruption in ports in Southern Africa ${ }^{49}$ but research by Sequeira found a 36 per cent probability of paying a bribe at Durban port, which, although not sufficient to base broad inference on, does leave open the suggestion that bribery could result in selective implementation of the ISPS Code..$^{50}$ 


\section{Assessing Operation Phakisa: Development without security?}

Walker notes that, although South Africa's geography is defined by its maritime contours, the country has lagged behind others in recognising maritime security as a strategic priority, describing this element of policy as "inchoate". ${ }^{51}$ Unlike the many other countries discussed in this article, South Africa does not have an overtly stated maritime security strategy, although one is under development. The country took a leadership role in the development of such a strategy at SADC level, but this document remains classified and so does not provide insight into what South African thinking around maritime security issues and strategy in the region might constitute. One respondent who has seen the strategy noted that it is focused largely on piracy, particularly in the Western Indian Ocean, but commented that it offers no effective counter-piracy strategy. ${ }^{52}$ Ultimately, the move to classify this document (and likewise the national strategy development process) limits acceptance, and instead raises a number of questions around the content and quality of the strategy for observers relative to both SADC and South Africa as a leader in this bloc.

Walker says, "in the absence of these [policy] documents, South African maritime policies must instead be discerned through critically reviewing an assortment of policy frameworks" including -

- the regular South African Defence Reviews published by the Department of Defence;

- the country's White Paper on Foreign Policy (2011);

- the much-lauded but ill-implemented NDP;

- the Department of Transport's Comprehensive Maritime Transport Policy (2017); and

- the Knowledge Management Road Map for the South African Maritime Sector (developed by a collection of government departments and authorities).$^{53}$

The most seaward-facing initiative of government is thus Operation Phakisa, which seeks to leverage economic opportunities emanating from the sea to boost economic development and create jobs.

As noted earlier in this article, Operation Phakisa is a cross-cutting interdepartmental initiative that brings together strands of ocean-based plans and priorities from across government. Phakisa was developed under the 'big fast results' methodology, known to have been successful in Malaysia, and which would garner quick wins in economic development for South Africa. Nonetheless, the security-development nexus appears all but absent from the higgledy-piggledy assortment of Phakisa projects. One might argue that the security-development nexus is acknowledged under the 'Oceans Economy Lab' and its Marine Protection Service and Ocean Governance component. According to Phakisa's website, however, one of the ten 'quick wins' of the first phase under this component of the operation is an enhanced and coordinated enforcement programme, where first results were expected by March 2016. Yet, available documents 
to this effect on the Operation Phakisa website date back to 2014, while annual reports lack detail, and this has not been remedied through the release of Department of Defence reviews either. ${ }^{54}$ A media statement issued in June 2018 by the DEA elucidates that the programme (known as Initiative 5) has focused largely on compliance around marine pollution, fisheries, ocean acidification and mining, but does not seem to address those (criminal) actors, which may not have any legitimate place within the system against which compliance can be checked. In this sense, Phakisa seems to focus on good governance rather than security, thereby missing the link between security and the development it seeks.

It is interesting also, from this perspective, to note that coordination for different streams resides with different departments, while the operation as a whole is coordinated by the Department of Planning, Monitoring and Evaluation (DPME), which is not in particular a locus of domestic power. The division of labour becomes yet more curious when one considers that, despite the fact that many of the goods smuggled into South Africa make their way into the country via terrestrial borders and the key international airport in Johannesburg, operations for the seizure of drugs have been conducted under the auspices of Operation Phakisa, according to defenceWeb. ${ }^{55}$ Phakisa, it is clear, suffers from haphazard thinking around responsibility, which seems to be characterised by a 'most-of-government' rather than a 'whole-of-government' approach. Moreover, departments have shown limited capacity for co-operation, and face challenges in capacity development as budgets become more constrained in the context of economic contraction. This further challenges the adaptability of state agencies to respond to the ebb and flow of maritime security threats as well as their metamorphosis.

Masie and Bond argue that Operation Phakisa has been characterised "in reality, by small, slow failures in planning and implementation, with miserable overall outcomes for the economy, polity, society and ecology", explaining that the initiative has been "overhyped". ${ }^{56}$ Indeed, Phakisa has been a buzzword, says one observer, particularly under the Zuma administration, and has lost steam under the watch of the current president, Cyril Ramaphosa. ${ }^{57}$

\section{Recommendations: How can or should Phakisa be securitised?}

Van Wyk argues that South Africa has historically recognised the strategic value of its geographic location, which marries two oceans and has formed part of important historical trade routes, as well as being of "major economic, strategic and ideological value during the Cold War period and prior to 1994", when South Africa entered its democratic era. ${ }^{58}$ She notes that this continues in the twenty-first century because South Africa has the continent's most sophisticated maritime industry. While this latter point is undoubtedly true, this article argues that South Africa's attention to its maritime domain has not been in clear focus, perhaps also because, outside of the colonial period, South Africa is not a traditionally maritime nation. Much more can be done to enhance the development of the ocean-based economy by engaging in a deeper strategic thinking exercise and placing greater emphasis on securing the maritime domain and the resources it contains. 
Strategic thinking would, indeed, be a suitable place for government to start by developing an actual strategy that is dedicated to maritime security and that addresses, as any domestic security dialogue should, the country's national interest and primary objectives based on a long-term vision. The Department of Transport is indeed in the process of developing a strategy, as mentioned, but developing one that is encompassing of the abovementioned issues and sees the way forward for integrated responses will be a tall order. The strategy will need to work hand in hand with Operation Phakisa via a combined approach in the achievement of what would thus be intrinsically linked goals. In furtherance of this, some thought may also be given to where responsibility is located in order to ensure a coordinated, whole-of-government approach, led by an appropriate domestic actor with sufficient voice and power to afford Phakisa the best possible chance at success.

Of course, there are the perennial challenges of budgetary constraints (also alluded to earlier), such as lacking human capacity, insufficient political will and limited policy implementation with which to contend. As far as the elements of defence and security are concerned, these of course exist within the context of a declining defence budget and the concomitant challenge of ageing and inadequate equipment, particularly for patrolling South Africa's vast maritime domain. In order for Operation Phakisa to be successful, a sufficient budgetary allocation has to be made, but this comes up against competing interests in a country whose fiscal health is flailing. The same can be said for the SAPS and the necessary resources and assets required to police nearshore.

With this in mind, it may be helpful for South Africa to dust off the NDP, update it, and proceed with a united and coherent long-term vision for the country, which it actually intends to implement. Conversely, South Africa might consider how the priorities of Operation Phakisa and the Blue Economy more generally fit into its security policy framework when this is renewed, thus bringing the security-development nexus into sharper focus. Part of this exercise is likely to be an ideological exploration: South Africa has no stated enemies, and the perspective from which it views this security position clearly informs the manner and extent to which it chooses to invest in its security forces. Realistically, however, the sea-based challenges discussed in this article cannot be resolved without greater budgetary consideration for the Ministry of Defence in particular - while the same can be said for land-based challenges and the relevant ministries that must address them. These should be reflected upon by government within the context of the extended period needed to (re)build operational capability. ${ }^{59}$

Further to this, such an exercise in strategic thinking around ocean opportunities may render South Africa with the fringe benefits of identifying international partnerships and promote its maritime or naval diplomacy. As the country straddles two oceans, partnerships within the Indian Ocean (such as through the Indian Ocean Rim Association [IORA]), and the Atlantic Ocean (via the India-Brazil-South Africa grouping) should be re-evaluated. Indeed, South Africa can learn from similar exercises undertaken by the likes of the EU, the United Kingdom, India and others. Such strategic thinking would also allow for Pretoria to utilise its platform on the world stage via the kinds of opportunities it has had, and may have in future, inter alia, the country's seat 
on the United Nations Security Council, its presidency of IORA, and membership of groupings, such as Brazil-India-China-South Africa, for meaningful gain domestically, but also for the continent which it represents.

\section{Conclusion}

While considerable attention and resources have been directed toward achieving security on land, similar efforts to secure Africa's maritime domain have been feeble mainly because the maritime dimension was historically ignored in most local, national, sub-regional and continental strategies. ${ }^{60}$ Indeed, while this is being remedied elsewhere, it is becoming clear that there is an urgent need for a review of South Africa's maritime arena, the context within which Operation Phakisa exists, to understand truly the challenges the country faces emanating from the sea, and how this will affect the development South Africa wishes to derive from it. 'Big fast results' for development simply cannot be seen with security, and government must thus, with urgency and a sense of sobriety, revisit its policy frameworks and the way in which they integrate in order to foster an all-of-government approach. This will surely allow for a clearer vision of how and where South Africa can partner with members of the international community and relevant international organisations to breathe life into the Blue Economy aspiration. Moreover, these issues present South Africa with an opportunity for the projection of its foreign policy imperatives in Africa and the world at large.

To be sure, any planning or strategy-development process should include a thorough assessment of threats and opportunities, strengths and weakness, which should be reflected in the policy document or strategy that results. Adequate and actionable plans must then be put in place accordingly. Ultimately, the vast possibilities presented to us by the oceans cannot be harnessed unless there is a concerted effort to protect them. 


\section{ENDNOTES}

${ }^{1}$ Senior Researcher, South African Research Chairs Initiative (SARChI) Chair: African Diplomacy and Foreign Policy, University of Johannesburg, South Africa. B-Ring 206, Auckland Park Kingsway Campus, University of Johannesburg, Kingsway Road, Auckland Park, South Africa.lisao@uj.ac.za

${ }^{2}$ Department of Planning, Monitoring and Evaluation. "Operation Phakisa". 2017. $<$ http://www.operationphakisa.gov.za/Pages/Home.aspx $>$ Accessed on 27 April 2019.

${ }^{3}$ Council for Scientific and Industrial Research. "Research Innovation and Knowledge Management Road Map for the South African maritime sector". 2017. $<$ http://saimi.co.za/downloads/2017\%20Maritime\%20Road\%20Map\%20 -\%20Sector\%20Coordination\%20Report_1.pdf $>$ Accessed on 27 April 2019.

${ }^{4}$ V Johansson. "The security and development nexus: A policy analysis". Published Masters thesis. Linnaeus University, 2014. <http://www.diva-portal.org/ smash/get/diva2:784285/FULLTEXT01.pdf> Accessed on 27 April 2019.

${ }^{5} \mathrm{H}$ Hrychuk. "Combating the security-development nexus?" International Journal Summer. 2009. 825-842.

${ }^{6}$ B Hettne. "Development and security: Origins and future". Security Dialogue 41/1. 2010. 31-52.

${ }^{7}$ International Peace Academy. "The security-development nexus: Conflict, peace and development in the $21^{\text {st }}$ century". 2004. $<$ https://www.ipinst.org/wp-content/ uploads/publications/security_dev_nexus.pdf $>$ Accessed on2 7 April 2019.

${ }^{8}$ Ibid.

${ }^{9} \mathrm{C}$ Green \& L Otto. Resource abundance in Mozambique: Avoiding conflict, ensuring prosperity. Occasional paper no. 173. Johannesburg: South African Institute of International Affairs, 2014.

${ }^{10} \mathrm{E}$ Swanepoel. The nexus between prosperity in the African maritime domain and maritime security. Policy briefing no. 163. Pretoria: South African Institute of International Affairs, 2017.

${ }^{11}$ L Otto. "Why regional efforts are key to Africa's maritime security". The Conversation. 16 January 2018. <https://theconversation.com/why-regional-efforts-are-key-to-africas-maritime-security-89813> Accessed on 19 March 2018.

${ }^{12}$ Swanepoel op. cit., pp. 2-3.

${ }^{13}$ United Nations. "Goal 14: Conserve and sustainably use the ocean, seas and marine resources". 2017. < $\underline{\text { http://www.un.org/sustainabledevelopment/oceans/ }>}$ Accessed on 19 March 2018.

${ }^{14}$ Ibid. 
${ }^{15} \mathrm{~J}$ van Wyk. "Defining the blue economy as a South African strategic priority: Toward a sustainable $10^{\text {th }}$ province?" Journal of the Indian Ocean Region 11/2. 2015. 153-169.

${ }^{16}$ Council of the European Union. "European Union Maritime Security Strategy". $2014<$ https://register.consilium.europa.eu/doc/srv?l=EN\&f=ST $\% 20$ $11205 \% 202014 \% 20$ INIT $>$ Accessed on 27 April 2019.

${ }^{17}$ HM Government. "The UK National Strategy for Maritime Security”. 2014. $<\underline{\text { https://assets.publishing.service.gov.uk/government/uploads/system/ }}$ uploads/attachment data/file/322813/20140623-40221_national-maritime-strat-Cm 8829 accessible.pdf $>$ Accessed on 27 April 2019.

${ }^{18}$ US Department of State. “The National Strategy for Maritime Security”. 2005. $<$ https://www.state.gov/documents/organization/255380.pdf $>$ Accessed on 27 April 2019.

${ }^{19}$ AE Abdenur \& DM Neto. Brazil's maritime strategy in the South Atlantic: The nexus between security and resources. Occasional paper no. 161. Johannesburg: South African Institute of International Affairs, 2013.

${ }^{20}$ Indian Ministry of Defence. "Ensuring secure seas: Indian maritime security strategy". 2015. < https://www.indiannavy.nic.in/sites/default/files/Indian Maritime Security_Strategy_Document_25Jan16.pdf $>$ Accessed on 27 April 2019.

${ }^{21}$ DP Shah. "China's maritime security strategy: An assessment of the White Paper on Asia-Pacific Security Cooperation". Maritime Affairs: Journal of the National Maritime Foundation of India 12/1. 2017. 1-13.

${ }^{22}$ K Kuno, Patrick Cronin, Alexandre Sheldon-Duplaix \& David Winkler. “Japan's maritime strategy". 2011. <https://carnegieendowment.org/2011/05/26/japan-s-maritime-strategy-pub-47174> Accessed on 27 April 2019.

${ }^{23}$ African Union. “2050 Africa’s Integrated Maritime Strategy”. 2012. <https://au.int/ en/documents-38> Accessed on 27 April 2019.

${ }^{24}$ T Walker. Securing a sustainable oceans economy: South Africa's approach. Southern Africa report no. 14. Pretoria: Institute for Security Studies, 2018.

${ }^{25}$ Van Wyk op. cit., p. 4.

${ }^{26}$ Otto op. cit.

${ }^{27}$ A Royeppen. "Rethinking challenges to SADC's maritime security model". 2014. $<$ http://www.igd.org.za/11204-rethinking-challenges-to-sadc-s-maritime-security-model> Accessed on 27 April 2017.

${ }^{28}$ Maritime security researcher, personal interview, Pretoria, 17 January 2019.

${ }^{29}$ Otto op. cit., p. 31.

${ }^{30}$ Ibid., p. 34. 
${ }^{31}$ Department of Planning, Monitoring and Evaluation. "Unlocking the economic potential of South Africa's oceans". 2014. <www.operationphakisa.gov. za/operations/oel/pmpg/Marine $\% 20$ Protection $\% 20$ and $\% 20$ Govenance $\% 20$ Documents/Marine $\% 20$ Protection $\% 20$ and $\% 20$ Govenance/OPOceans $\% 20$ MPSG\%20Executive\%20Summary.pdf $>$ Accessed on 27 April 2018.

${ }^{32}$ T Walker. "Avoiding the siren's song: Will Operation Phakisa deliver prosperity?" Institute for Security Studies. 2014. <https://www.issafrica.org/iss-today/ avoiding-the-sirens-song-will-operation-phakisa-deliver-prosperity $>$ Accessed on 27 April 2018.

${ }^{33}$ Naval official, personal interview, Johannesburg, 14 May 2019.

${ }^{34}$ Van Wyk op. cit., pp. 165-166.

${ }^{35}$ AF Senu. "The global assemblage of multi-centred stowaway governance". Unpublished Doctoral thesis. Cardiff University, 2018.

${ }^{36}$ M Loewe. "Chinese skippers appear in court for illegal fishing in South African waters". Business Day. 25 May 2016. <http://www.bdlive.co.za/business/ agriculture/2016/05/25/chinese-skippers-appear-in-court-for-illegal-fishingin-sa-waters $>$ Accessed on 27 April 2018.

${ }^{37}$ S Kings. "SA at sea over illegal fishing in its waters". Mail \& Guardian. 19 May 2016. <http://mg.co.za/article/2016-05-19-00-sa-at-sea-over-illegal-fishingin-its-waters $>$ Accessed on 27 April 2018.

${ }^{38}$ Overseas Development Institute. 'Western Africa’s missing fish'. 2016. <https://www.odi.org/sites/odi.org.uk/files/resource-documents/10665.pdf> Accessed on 27 April 2019.

${ }^{39}$ E de Coning \& E Witbooi. "Towards a new 'fisheries crime' paradigm: South Africa as an illustrative example”. Marine Policy 60. 2015. 208-215.

${ }^{40}$ Kings op. cit.

${ }^{41}$ A van Heerden. "Drug trafficking: The use of South African drug mules in crossborder smuggling”. Published Masters thesis. University of South Africa, 2014.

${ }^{42}$ Engineer at the Council for Scientific and Industrial Research, personal interview, Pretoria, 27 June 2017.

${ }^{43}$ CSIR. "CSIR's SeaFAR detects massive bilge dump". 2016. $<$ https://www.csir.co.za/csir\%E2\%80\%99s-seafar-detects-massive-bilgedump $>$ Accessed on 27 April 2018.

${ }^{44}$ News24Wire. "South Africa pushes ahead with ocean monitoring satellite programme". Engineering News. 28 February 2019. < http://www.engineeringnews.co.za/article/south-africa-pushes-ahead-with-ocean-monitoring-satellite-programme-2019-02-28/rep_id:4136> Accessed on 4 March 2019.

${ }^{45}$ Maritime security researcher, personal interview, Pretoria, 17 January 2019. 
${ }^{46}$ Transnet. "Port security South Africa". 2007.

$<$ https://www.transnetnationalportsau thority.net/Port\%20Operations/Pages/Security.aspx $>$ Accessed on 1 March 2019.

${ }^{47}$ Ibid.

${ }^{48}$ S Ramsaroop. "Understanding the International Ship and Port Facility Security (ISPS) code: An examination of the implementation and effectiveness of the ISPS code". Unpublished Masters thesis. University of KwaZulu-Natal, 2016.

${ }^{49}$ M Chêne. "Literature review on corruption at ports and border points in Southern Africa". U4. 2013. <https://www.u4.no/publications/literature-review-oncorruption-at-ports-and-border-points-in-southern-africa.pdf $>$ Accessed on 27 April 2019.

${ }^{50}$ S Sequeria. "Investigation and tackling corruption in African ports". The London School of Economics and Political Science. 2015. < $<$ http://www.lse.ac.uk/ Research/Assets/impact-pdf/Sequeria.pdf $>$ Accessed on 27 April 2019.

${ }^{51}$ Walker op. cit., p. 5.

${ }^{52}$ Maritime security researcher op. cit.

${ }^{53}$ Walker op. cit., p. 5.

${ }^{54}$ Maritime security researcher op. cit.

${ }^{55}$ Ibid.

${ }^{56} \mathrm{Ibid}$.

${ }^{57}$ Ibid.

${ }^{58}$ Van Wyk op. cit., pp. 155-156.

${ }^{59}$ Naval official op. cit.

${ }^{60}$ Africa Center for Strategic Studies. "The process of national maritime security strategy development in Africa". 2016.

$<$ https://africacenter.org/wp-content/uploads/2016/07/The-Process-of-National-Maritime-Security-Strategy-Development-in-Africa.pdf $>$ Accessed on 27 April 2019. 